\title{
Fertility desire and associated factors among women on the reproductive age group of Antiretroviral treatment users in Jimma Town, South West Ethiopia
}

\author{
Teshome Shiferaw ${ }^{1}$, Getachew Kiros ${ }^{1}$, Zewdie Birhanu ${ }^{1}$, Hailay Gebreyesus ${ }^{2}$, Tesfay Berhe ${ }^{2 *}$ \\ and Mebrahtu Teweldemedhin ${ }^{3}$
}

\begin{abstract}
Objectives: HIV remained the major cause of death in women of reproductive age worldwide. There is limited evidence regarding the fertility desire of HIV positive women receiving HIV care in the study area. Therefore, facility based cross-sectional study was conducted from March to April 2017 to assess fertility desire of HIV positive women and associated factors among mothers in receiving HIV care Jimma town, Southwest Ethiopia. Simple random sampling technique was taken to draw the sample after stratification. Data were analyzed using SPSS version 21 and statistical significance was declared at $P$ value less than 0.05 .

Results: This finding showed that, 175 (46.8\%) of the Antiretroviral therapy users had fertility desire with those significantly associated factors; women in the age $18-29$ years [AOR $=4.05,95 \% \mathrm{Cl} 1.24-13.33]$, being married $[\mathrm{AOR}=0.32$, $95 \% \mathrm{Cl}(0.13-0.78)]$, having diploma educational level $[A O R=5.34,95 \% \mathrm{Cl} 1.10,15.60]$, having only boys or girls children $[A O R=2.79,95 \% \mathrm{Cl}(1.24-6.25)]$, having 18-36\$ monthly income [AOR $=1.27,95 \% \mathrm{Cl}(1.56-10.67)]$, Partner's HIV status $[\mathrm{AOR}=3.56,95 \% \mathrm{Cl}(3.02-9.33)]$ and non use of contraceptives $[\mathrm{AOR}=2.57,95 \% \mathrm{Cl}(1.08-6.13)]$. Fertility desire in the study area was high. Strengthening PMTCT service should consider fertility desire of mothers living with HIV.
\end{abstract}

Keywords: ART users, Women, Fertility desire, Jimma, Ethiopia

\section{Introduction}

HIV is one of the major causes of mortality in women of reproductive age worldwide. Sub-Saharan Africa has continued to bear the greatest burden of HIV; approximately $56 \%$ of new infections of the adult population constitute women [1]. Since the introduction of antiretroviral therapy (ART), the life expectancy of HIV-positive women has noticeably increased but challenged by many reproductive health issues. In the year 2013, around 1.5 million women living with HIV gave birth. However, a large fraction of (3.2 million) children below the age of 15 years were carriers accounting for $9.1 \%$ of all people living HIV

*Correspondence: alnorasanti@gmail.com

2 Department of Public Health, College of Health Science, Aksum University, P. O. Box: 298, Aksum, Ethiopia

Full list of author information is available at the end of the article due to vertical transmission [2-4]. Hence, programs providing highly effective treatment and prophylaxis interventions can have efficient power in reducing new HIV infections in Children [5].

The critical step towards reducing MTCT of HIV is the main pillar of the international standards for a comprehensive approach [6]. Even though PMTCT programs accounted for a $5 \%$ reduction in MTCT in developing countries, the coverage of effective ART regimens was 57\% [7]. Similarly, low PMTCT coverage and poor integration with maternal services have been documented as the main challenge of the Ethiopian government [8].

In countries like Ethiopia, the complex relationship between HIV/AIDs and the high rate of fertility further threatens the preventive strategies towards the vertical spread of HIV [9]. However, Women living with HIV like 
the general population still prefer to give birth [10-14]. Because most HIV positive couples are in the reproductive age group, they experience difficulties in their sexual life and childbearing $[13,15]$.

Earlier to the PMTCT programs, health care providers have been dispiriting women living with HIV from having children in order to avoid new infections in children through many women continued to give birth with the knowledge for consequences [14-21]. Even after antiretroviral treatment, there is evidence that healthcare providers have advised women living with HIV to avoid pregnancy [21-24]. However, it is evidenced in a number of studies that many HIV positive women have children and wish more children [25-27], emphasizing the need for comprehensive care for this population who can have a safe and healthy pregnancy.

In case people living with HIV desire to have children, counseling by their health care providers has critical role to assure planned pregnancies, and minimizing prevention of mother to child transmission [28]. However, in many settings a large majority of HIV-positive women who desire more children have not discussed about reproductive health and childbearing with their health care providers [29-31]. Besides, contraception strategy has also been evidenced by the world health organization as a key strategy to reduce new infant infections [32]. In Ethiopia, studies conducted so far indicated that fertility desire in women living with HIV ranged from 34 to $45 \%$ [33-36]. However, there is still a paucity of scientific studies on the associated factors of fertility desire in the study group. Therefore, this study was aimed to assess the fertility desire and its associated factors among HIV positive women in the reproductive age group under antiretroviral treatment in Jimma town, south- west Ethiopia.

\section{Main text \\ Methods \\ Study area and period}

This investigation was done in three public health facilities at Jimma town which is $355 \mathrm{~km}$ far from Addis Ababa, Ethiopia to the south-west. According to the town Administrative office 2017 report, the town has an estimated 190,125 total population. The study was done from March 26 to April 30, 2017.

\section{Study design and population}

A facility-based cross-sectional study was conducted among women in the reproductive age group receiving ART follow-up care in the town. The study included women with HIV, aged 18 to 49 years who made at least one visit to the ART unit.

\section{Sample size and sampling technique}

The sample size was calculated using a single population proportion formula taking the prevalence of fertility desire among HIV-positive women's $42.1 \%$, margin of error $5 \%$ and adding $10 \%$ for non-response rate then finally we obtained 374 respondents. In order to have a representative respondent from the three ART units stratified sampling technique was used and the number of study subjects in each health facility was determined using Proportional allocation and individuals were taken using simple random sampling. The primary outcome variable for the study (fertility desire) was measured by answers to the question: "Are you currently planning to have (more) children in the near future?" Women's were free to respond "Yes", "No", or "Don't know, the small proportion of women who responded "Don't Know" (if 5\%) were included in the "No" category [33]. Finally, a positive ("Yes") response to the above question was observed as fertility desire.

\section{Data collection technique}

Data were collected using a pre-tested structured selfadministered questionnaire. The questionnaire was grouped into four categories (61 item questions or explanatory variables); socio-demographic information, HIV/AIDS disease Related factors, Knowledge of HIV transmission, Reproductive Factors and Perceived social pressure. Training was given for data collectors and supervisors on how to conduct interview and content of the questionnaire. Data was collected by four clinical nurses under two BSc. nurse supervisors and principal investigator. Daily Supervision was conducted by the supervisors and principal investigator.

\section{Data exploration and method of analysis}

Data was entered into EPI Data 3.1, for controlling data entry errors, and then exported to SPSS software version 21 for analysis. We use descriptive statistics and graphical techniques to explore the entire variables of the study.

Furthermore, the Bi-variant analysis was used to select best predictor variables and those variables showed significant association at a p-value of less than 0.2 were entered into multiple logistic regression models and a p-value of $<0.05$ was used to see the significance in the final predictors of fertility desire. Strength and direction of the association also presented using odds ratios relative to the reference category and 95\% confidence levels. 


\section{Results}

Socio-demographic characteristics of the study respondents In this survey, 374 respondents were participated in making a response rate of $100 \%$. Almost half 184 $(49.2 \%)$ of the respondents who were involved in this study were in the age group of 30-39 years' see blow (Table 1).

\section{Fertility desire of respondents}

Table 2 shows that respondents who want children in the future were 175 (46.8\%) and those who do not want were 199 (53.2\%). Out of the 374, 172 (46.0\%) discussed their Child need with health profession/counselors. From the total interviewed PLHIV's, 50 (13.4\%) want to have one or two biological live children whereas $91(24.3 \%)$ want to have three to four children.

Table 1 Socio-demographic characteristics of women attending ART clinic in Jimma Town public health facilities Southwest Ethiopia, April, 2017

\begin{tabular}{|c|c|c|c|}
\hline Socio-demographic variables & Categories & Frequency (n) & Percent (\%) \\
\hline \multirow[t]{2}{*}{ Residence $(n=374)$} & Urban & 303 & 81.0 \\
\hline & Rural & 71 & 19.0 \\
\hline \multirow[t]{4}{*}{ Marital status $(n=374)$} & Married & 201 & 53.7 \\
\hline & Divorced/separated & 91 & 24.3 \\
\hline & Widowed & 55 & 14.7 \\
\hline & Never Married & 27 & 7.2 \\
\hline \multirow[t]{3}{*}{ Age category $(n=374)$} & $18-29$ & 161 & 43.0 \\
\hline & $30-39$ & 184 & 49.2 \\
\hline & $40-49$ & 29 & 7.8 \\
\hline \multirow[t]{6}{*}{ Ethnicities $(n=374)$} & Oromo & 180 & 48.1 \\
\hline & Amhara & 61 & 16.3 \\
\hline & Dawuro & 46 & 12.3 \\
\hline & Kefa & 41 & 11.0 \\
\hline & Tigrean & 24 & 6.4 \\
\hline & Others (Yem, Gurage) & 22 & 5.9 \\
\hline \multirow[t]{5}{*}{ Religion $(n=374)$} & Orthodox & 156 & 41.7 \\
\hline & Muslim & 142 & 38.0 \\
\hline & Protestant & 70 & 18.7 \\
\hline & Catholic & 4 & 1.1 \\
\hline & Others (heaven) & 2 & 0.5 \\
\hline \multirow[t]{8}{*}{ Occupational $(n=374)$} & Daily labor & 82 & 21.9 \\
\hline & House wife & 70 & 18.7 \\
\hline & Merchants & 61 & 16.3 \\
\hline & Private employed & 57 & 15.2 \\
\hline & Government employed & 45 & 12.1 \\
\hline & Commercial sex worker & 30 & 8.0 \\
\hline & Student & 13 & 3.5 \\
\hline & Farmer & 16 & 4.3 \\
\hline \multirow[t]{6}{*}{ Educational status $(n=374)$} & Formal education (1-10) & 122 & 32.6 \\
\hline & Unable to read and write & 114 & 30.5 \\
\hline & No formal education & 66 & 17.6 \\
\hline & Diploma & 40 & 10.7 \\
\hline & Preparatory & 25 & 6.7 \\
\hline & University degree & 7 & 1.9 \\
\hline \multirow[t]{4}{*}{ Family income $(n=374)$} & No income & 15 & 4.0 \\
\hline & $0.04-17.8 \$$ & 81 & 21.7 \\
\hline & $18-36 \$$ & 207 & 55.3 \\
\hline & $>36 \$$ & 71 & 19.0 \\
\hline
\end{tabular}


Table 2 Fertility desire among women living with HIV attending ART units at Jimma town, Southwest Ethiopia, April, $2017(n=374)$

\begin{tabular}{|c|c|c|c|}
\hline Variables & Categories & Frequency & Percent \\
\hline \multirow[t]{2}{*}{ Would you like to have a child in the near future? } & No & 199 & 53.2 \\
\hline & Yes & 175 & 46.8 \\
\hline \multirow[t]{2}{*}{ Have you discussed your fertility desire with health profession/counselor? } & No & 202 & 54.0 \\
\hline & Yes & 172 & 46.0 \\
\hline \multirow[t]{4}{*}{ How many children would you like to have? } & None & 199 & 53.2 \\
\hline & 3-4 children & 91 & 24.3 \\
\hline & 1-2 children & 50 & 13.4 \\
\hline & I don't know & 34 & 9.1 \\
\hline \multirow[t]{3}{*}{ Now, are you using any method of contraceptive to prevent pregnancy? } & Yes & 200 & 53.5 \\
\hline & No & 140 & 37.4 \\
\hline & Currently pregnant & 34 & 9.1 \\
\hline \multirow[t]{2}{*}{ Do know your CD4 count? } & Yes & 237 & 63.4 \\
\hline & No & 137 & 36.6 \\
\hline \multirow[t]{3}{*}{ Desire at least one child } & Yes & 93 & 24.9 \\
\hline & No & 82 & 21.9 \\
\hline & Not want a child & 199 & 53.2 \\
\hline \multirow[t]{3}{*}{ Is your fertility desire related with strengthening marriage? } & Yes & 58 & 15.5 \\
\hline & No & 117 & 31.3 \\
\hline & No, I just want a child & 199 & 53.2 \\
\hline \multirow[t]{3}{*}{ Uses ART/PMTCT to prevent transmission of the virus } & Yes & 72 & 19.3 \\
\hline & No & 103 & 27.5 \\
\hline & Not want a child & 199 & 53.2 \\
\hline \multirow[t]{3}{*}{ Desire to replace died baby before } & Yes & 29 & 7.8 \\
\hline & No & 146 & 39.0 \\
\hline & Not want a child & 199 & 53.2 \\
\hline
\end{tabular}

\section{Fertility desire and associated factors}

Results of the multiple logistic regression model showed that, marital status, age, educational level, monthly family income, child's biological sex, Partner HIV status and Perceived social expectation of that partner, using contraceptive method, Parent, and community pressure to have children were found to be significantly related with fertility desire (p-value $<0.05$, Table 3 ).

The odds of having fertility desire was 4.05 times higher among women aged 18-29 years as compared to those aged $40-49$ years $[\mathrm{AOR}=4.05, \mathrm{p}=0.021,95 \%$ CI $1.24-$ 13.33], the odds of having fertility desire was 4.9 times higher among married women as compared to those divorced [AOR $=4.967, \mathrm{p}=0.027,95 \%$ CI 1.203-20.499] and the odds of having fertility desire was 0.32 times less among widowed women as compared to the divorced $[\mathrm{AOR}=0.32, \mathrm{p}=0.012,95 \% \mathrm{CI} 0.13-0.78)]$. The odds of having fertility desire was 5.3 times higher among diploma holder women as compared to women who completed University degree $[\mathrm{AOR}=5.34, \mathrm{p}=0.037,95 \%$ CI 1.10, 15.60]. Concerning income, the odds of having fertility desire was 1.79 times higher among those women whose monthly family income $18-35 \$$ as compared to no income $[\mathrm{AOR}=1.79, \mathrm{p}=0.001,95 \% \mathrm{CI} 1.56-10.66)]$. The odds of having fertility desire was 3.7 times higher among women with HIV positive partner as compared to those without a sexual partner $[\mathrm{AOR}=3.7, \mathrm{p}=0.054,95 \% \mathrm{CI}$ 1.03-10.49]. The odds of having fertility desire were 1.78 times higher and 2.79 times higher among mothers having children with biological sex of "all girls" and "all boys" respectively (Table 3).

\section{Discussion}

The findings of this study show that $46.8 \%$ of the study subjects need to have children; almost comparable with the previous studies conducted in Tigray and Addis Ababa, $45.5 \%$ and $44 \%$ fertility desire respectively $[37,38]$ but higher as compared to the previous studies conducted in other parts of Ethiopia, 24\% and $15.7 \%$ desire level respectively $[39,40]$. With this regard, our figure is lower than previous findings elsewhere [41-43]. This difference might be explained by socioeconomic and cultural differences or other health-related factors including counseling skills. In 
Table 3 Factors associated with fertility desire among HIV-positive women of reproductive age in Jimma town Southwest Ethiopia, $2017(n=374)$

\begin{tabular}{|c|c|c|c|c|c|}
\hline Variables & Total number & $\begin{array}{l}\text { Fertility desired } \\
\text { Number ("yes") }\end{array}$ & $\operatorname{COR}(95 \% \mathrm{Cl})$ & p-value & AOR \\
\hline \multicolumn{6}{|l|}{ Age } \\
\hline $18-29$ & 161 & $91(56.5)$ & $4.97(1.93,12.82)^{*}$ & 0.021 & $4.05(1.24,13.33)$ \\
\hline $30-39$ & 184 & $78(42.4)$ & $2.82(1.09,7.25)^{*}$ & 0.071 & $2.92(0.91,9.35)$ \\
\hline $40-49$ & 29 & $6(20.7)$ & 1 & & 1 \\
\hline \multicolumn{6}{|l|}{ Marital status } \\
\hline Never married & 27 & $13(48.1)$ & $1.42(0.59,3.37)$ & 0.243 & $2.011(0.622,6.501)$ \\
\hline Married & 201 & $112(55.7)$ & $1.92(1.16,3.18)$ & 0.027 & $4.967(1.203,20.499)$ \\
\hline Widowed & 55 & $14(25.5)$ & $0.52(0.916,4.010)$ & 0.012 & $0.32(0.13,0.78)$ \\
\hline Divorced & 91 & $36(39.6)$ & 1 & & 1 \\
\hline \multicolumn{6}{|l|}{ Educational status } \\
\hline Can't read and write & 27 & $12(44.4)$ & $1.27(0.56,2.87)$ & 0.340 & $1.96(0.49,7.94)$ \\
\hline Read and write but not formal & 48 & $22(45.8)$ & $1.35(0.71,2.56)$ & 0.935 & $1.054(0.300,3.699)$ \\
\hline Formal education & 73 & $42(57.5)$ & $2.15(1.24,3.74)^{*}$ & 0.982 & $1.01(0.312,3.21)$ \\
\hline Preparatory & 19 & $10(52.6)$ & $1.77(1.47,4.56)$ & 0.672 & $1.38(0.31,6.28)$ \\
\hline Diploma & 23 & $18(78.3)$ & $5.7(2.04,16.12)^{*}$ & 0.037 & $5.34(1.10,15.60)$ \\
\hline University degree & 184 & $71(38.6)$ & 1 & & 1 \\
\hline \multicolumn{6}{|l|}{ Monthly family income } \\
\hline Less than 500 ETB & 81 & $98(63.22)$ & $1.514(0.492,4.657)$ & 0.926 & $1.077(0.224,5.188)$ \\
\hline 500-1000 ETB & 207 & $109(52.7)$ & $1.27(1.02,7.103)^{*}$ & 0.001 & $1.79(1.56,10.669)$ \\
\hline $1001-5000$ ETB & 71 & $45(63.4)$ & $1.978(1.106,3.352)^{*}$ & 0.146 & $1.699(.832,3.468)$ \\
\hline No income & 15 & $7(46.7)$ & 1 & & 1 \\
\hline \multicolumn{6}{|l|}{ Duration of ART initiation } \\
\hline Less than 5 years & 218 & $95(43.57)$ & $0.645(0.348,0.897)$ & 0.135 & $0.655(0.377,1.141)$ \\
\hline Greater than 5 years & 156 & $85(54.48)$ & 1 & & 1 \\
\hline \multicolumn{6}{|l|}{ Children's biological sex } \\
\hline All girl/s & 82 & $42(52.5)$ & $1.49(1.22,2.609)^{*}$ & 0.001 & $1.780(1.522,3.852)$ \\
\hline Both boy/s and girl/s & 108 & $68(65.4)$ & $2.55(1.285,4.483)^{*}$ & 0.013 & $2.791(1.246,6.254)$ \\
\hline No living child & 88 & $65(75.58)$ & $4.18(2.301,7.573)$ & 0.143 & $3.732(1.667,8.355)$ \\
\hline All boy/s & 96 & $40(42.55)$ & 1 & & 1 \\
\hline \multicolumn{6}{|l|}{ Partner's HIV status } \\
\hline Positive & 136 & $76(55.9)$ & $2.533(1.585,4.048)^{*}$ & 0.04 & $3.77(1.03,10.49)$ \\
\hline Negative & 73 & $44(60.3)$ & $3.03(1.72,5.37)^{*}$ & 0.005 & $3.56(3.02,9.33)$ \\
\hline No partner & 165 & $55(33.3)$ & 1 & & 1 \\
\hline \multicolumn{6}{|l|}{ Partner's interest to have children } \\
\hline Yes & 163 & $109(66.9)$ & $4.44(2.86,6.85)^{*}$ & 0.000 & $3.125(1.811,5.37)$ \\
\hline No & 211 & $66(31.3)$ & 1 & & 1 \\
\hline \multicolumn{6}{|c|}{ Community pressure to have children } \\
\hline Yes & 180 & $104(57.8)$ & $2.37(1.56,3.703)^{*}$ & 0.015 & $1.94(1.14,3.31)$ \\
\hline No & 194 & $71(36.6)$ & 1 & & 1 \\
\hline \multicolumn{6}{|l|}{ Use of contraceptives } \\
\hline No & 140 & $70(50.0)$ & $1.41(1.212,5.512)^{*}$ & 0.032 & $2.575(1.082,6.128)$ \\
\hline Yes & 200 & $83(41.5)$ & 1 & & 1 \\
\hline
\end{tabular}

COR Crude odds ratio, $A O R$ adjusted odds ratio, $C l$ confidence interval *Significance for $A O R$ 
this study, getting at least one child to replace themselves, strengthening a relationship, and replacing died baby were major reasons for the fertility desire of women living with HIV.

This finding indicates that partner HIV status positive is $65.0 \%$ lower than the study conducted in Nekemt Southwest Ethiopia, among women partner tested positive was $70.6 \%$ [44]. These findings show that $53.5 \%$ of the participants use any method of contraceptive; higher than the finding in Addis Ababa 43.3\% [45].

In this study showed that, younger age (18-29 years), marital status (widowed and married, educational status diploma and above, having biological child sex difference both boys and girls, monthly family income (18-36\$), partners of HIV positive and negative status and use of contraceptives were significant factors of fertility desire similar to previous studies conducted elsewhere [44-46].

This study indicated that participants had adequate knowledge of HIV transmission by breastfeeding 316 (84.5\%) and using ART drug during pregnancy can reduce the risk of mother to children transmission 296 (79.1\%); as compared to the national survey $42 \%$ of women know that HIV can be transmitted by breastfeeding and $47 \%$ of risk of vertical transmission can be minimized by using ART during pregnancy [46].

Since access to ART has improved the life expectancy of people living with HIV, ART users are willing to contemplate childbearing. In comparison to HIV free women, there was no difference in the factors that influence pregnancy decisions specifically on partner's desire and age [47]. However, having children has great social importance in the Ethiopian context [48].

The study subjects who are unable to read and write had more (51\%) desire to have children as compared to those University degrees which may be due to the fact that participants who undergone education can recognize HIV induced burden. Besides, educational level may empower women to make self-decisions on reproductive issues [49].

According to the health sector transformation plan, Ethiopia is working to create HIV free generation by the year 2030. This demands strengthening prevention of MTCT and related strategies which one of the approaches may include addressing the fertility desire of people living with HIV. Therefore, this finding will inform on policy makers and health planners working on the prevention of MTCT at local and national level. As a limitation, because the study was facility based cross-sectional study, the findings may not represent the general HIV positive women.

\section{Conclusion}

This study revealed that almost half of the women under antiretroviral treatment had fertility desire. Being young age, married, having a biological child both sex (boys and girls), low monthly family income, diploma in educational status, none use of contraceptives, Partner's HIV status both positive and negative, parent and community pressure were obtained as significant factors of fertility desire. Considering the fertility desire of HIV positive women, health planners and service providers should strongly focus on counseling the mothers and preventing maternal HIV transmission.

\section{Limitation of the study}

The cross-sectional nature of the data, which makes it impossible to draw inferences about the direction of relations among study variables and the data are retrospective and thus are subject to recall bias.

\section{Additional file}

Additional file 1: Annex S1. Questionnaires to assess fertility desire among ART clients in Jimma area: English Version.

\section{Abbreviations}

AIDS: acquired immunodeficiency syndrome; ANC: Antenatal Care; ARV: antiretroviral; CD4T: 4 cells are "helper" cells; DHS: Demographic and Health Survey; $\mathrm{MOH}$ : Ministry of Health; HAART: Highly Active Antiretroviral Therapy; HIV: human immunodeficiency virus; NGO: Non-Governmental Organization; PLWHA: people living with HIV-AIDS; PMTCT: prevention mother to child transmission; STD: sexually transmitted disease; WHO: World Health Organization.

\section{Authors' contributions}

TS wrote the proposal, participated in data collection, analyzed the data and drafted the paper. ZB, HG, and GK approved the proposal with great revisions, participated in data analysis and revised subsequent drafts of the paper. MT, and TB participated in data analysis and drafted the paper. All authors read and approved the final manuscript.

\section{Author details \\ ${ }^{1}$ Department of Health Education and Behavioral Sciences, Jimma University, Jimama, Ethiopia. ${ }^{2}$ Department of Public Health, College of Health Science, Aksum University, P. O. Box: 298, Aksum, Ethiopia. ${ }^{3}$ Department of Medical Laboratory Sciences, College of Health Science, Aksum University, Aksum, Ethiopia.}

\section{Acknowledgements}

Our heartfelt thank goes to Jimma University College of Health Sciences for financial support. We are thankful to Jimma Town Health Office for their positive responses to facilitate the study and all study participants who voluntarily participated in this study.

\section{Competing interests}

This is to confirm that all authors have reviewed the submitted research article and approved the paper for submission. All authors also declare that they have no financial or non-financial competing interests. This manuscript has not been published elsewhere and is not under submission elsewhere. 


\section{Availability of data and materials}

All data is contained in the manuscript and Additional file 1 (English version questionnaire); other raw data will be provided to readers upon the request to Teshome Shiferaw.

\section{Consent for publication}

Not applicable.

\section{Ethics approval and consent to participate}

Ethical approval and clearance were obtained from the Jimma University Ethical clearance review board. Permeation letter was also obtained from Jimma Town Health Office and concerned health facilities presented to all participants. Interviews were conducted after outlining the study objectives and reading the information sheet. Verbal consent was obtained from all uneducated participants and written consent was obtained from all educated participants. Completed consent forms were detached from the questionnaire, a copy being given to the participants, and kept in a locked cabinet on completion of the interview.

\section{Funding}

This work was supported by Jimma University College of Health Sciences, post-graduate students' research fund only.

\section{Publisher's Note}

Springer Nature remains neutral with regard to jurisdictional in published maps and institutional affiliations.

Received: 24 November 2018 Accepted: 13 March 2019 Published online: 20 March 2019

\section{References}

1. UNAIDS. Global AIDS update; 2016. http://www.who.int/hiv/pub/arv/ global-aids-update-2016-pub/en/.

2. Joint United Nations Programme on HIV/AIDS (UNAIDS), 2014

3. UNAIDS: Report on the Global AIDS Epidemic. Geneva: Joint United Nations Programme on HIV/AIDS; 2012.

4. Nigatu T, Woldegebriel Y. Analysis of the prevention of mother-to-child transmission (PMTCT) service utilization in Ethiopia: 2006-2010. Reprod Health. 2011;16:8

5. World Health Organization. PMTCT strategic vision 2010-2015: preventing mother-to-child transmission of HIV to reach the UNGASS and Millennium Development Goals: moving towards the elimination of pediatric HIV, December 2009.

6. Sam D. Challenges of Containing New HIV Infections in Ethiopia: Unacknowledged Transmission Route, 2013; Capstone Collection: Paper 2610

7. UNAIDS report on the global AIDS epidemic: Joint United Nations program on HIV/AIDS; 2010

8. Guidelines for Prevention of Mother-to-Child Transmission of HIV in Ethiopia. Addis Ababa: FHAPCO, 2007.

9. Worku D. Fertility intension and demand for family planning among people on ART Follow up in North Wollo, Ethiopia. 2010. In: 21st Annual Public Health Conference.

10. Cooper D, Moodley J, Zweigenthal V, Bekker LG, Shah I, Myer L. Fertility intentions and reproductive health care needs of people living with HIV in Cape Town, South Africa: implications for integrating reproductive health and HIV care services. AIDS Behav. 2009;13(1):38-46.

11. Nattabi B, Li J, Thompson SC, Orach CG, Earnest J. Family planning among people living with HIV in post-conflict Northern Uganda: a mixed methods study. Conflict Health. 2011;5(1):18.

12. Cooper D, Harries J, Myer L, Orner P, Bracken H. "Life is still going on": reproductive intentions among HIV-positive women and men in South Africa. Soc Sci Med. 2007;65(2):274-83.

13. Yeatman SE. The impact of HIV status and perceived status on fertility desires in rural Malawi. AIDS Behav. 2009:13(1):12-9.

14. Craft SM, Delaney RO, Bautista DT, Serovich JM. Pregnancy decisions among women with HIV. AIDS Behav. 2007:11(6):927-35.
15. Nóbrega AA, Oliveira FA, Galvão MT, Mota RS, Barbosa RM, Dourado I, Kendall C, Kerr-Pontes LR. Desire for a child among women living with HIV/AIDS in northeast Brazil. AIDS patient care and STDs. 2007;21(4):261-7.

16. Craft SM, Delaney RO, Bautista DT, Serovich JM. Pregnancy decisions among women with HIV. AIDS Behav. 2007;11(6):927-35.

17. Bedimo-Rung AL, Clark AR, Dumestre J, Rice J, Kissinger P. Reproductive decision-making among HIV-Infected women. J Natl Med Assoc. 2005:97(10):1403.

18. Sowell RL, Murdaugh CL, Addy CL, Moneyham L, Tavokoli A. Factors influencing intent to get pregnant in HIV-infected women living in the southern USA. AIDS Care. 2002:14(2):181-91.

19. Nóbrega AA, Oliveira FA, Galvão MT, Mota RS, Barbosa RM, Dourado I, Kendall C, Kerr-Pontes LR. Desire for a child among women living with HIV/AIDS in northeast Brazil. AIDS Patient Care STDs. 2007;21(4):261-7.

20. Nebié Y, Meda N, Leroy V, Mandelbrot L, Yaro S, Sombié I, Cartoux M, Tiendrébeogo S, Dao B, Ouangré A, Nacro B. Sexual and reproductive life of women informed of their HIV seropositivity: a prospective cohor study in Burkina Faso. J Acq Immune Defic Syndr. 2001;28(4):367-72.

21. Sofolahan YA, Airhihenbuwa CO. Cultural expectations and reproductive desires: experiences of South African women living with HIV/AIDS (WLHA). Health Care Women Int. 2013;34(3-4):263-80.

22. Loutfy MR, Hart TA, Mohammed SS, Su D, Ralph ED, Walmsley SL, Soje LC, Muchenje M, Rachlis AR, Smaill FM, Angel JB. Fertility desires and intentions of HIV-positive women of reproductive age in Ontario, Canada: a cross-sectional study. PLoS ONE. 2009;4(12):e7925.

23. Ogilvie GS, Palepu A, Remple VP, Maan E, Heath K, MacDonald G, Christilaw J, Berkowitz J, Fisher WA, Burdge DR. Fertility intentions of women of reproductive age living with HIV in British Columbia, Canada. Aids. 2007; 1(21):S83-8

24. Nattabi B, Li J, Thompson SC, Orach CG, Earnest J. A systematic review of factors influencing fertility desires and intentions among people living with HIV/AIDS: implications for policy and service delivery. AIDS Behav. 2009;13(5):949-68.

25. Loutfy MR, Blitz S, Zhang Y, Hart TA, Walmsley SL, Smaill FM, Rachlis AR, Yudin MH, Angel JB, Ralph ED, Tharao W. Self-reported preconception care of hiv-positive women of reproductive potential a retrospective study. J Int Assoc Prov AIDS Care. 2014;13(5):424-33.

26. Kennedy VL, Serghides L, Raboud JM, Su D, Blitz S, Hart TA, Walmsley SL, Angel JB, Smaill FM, Ralph ED, Tharao WE. The importance of motherhood in HIV-positive women of reproductive age in Ontario, Canada. AIDS Care. 2014:26(6):777-84

27. Steiner RJ, Finocchario-Kessler S, Dariotis JK. Engaging HIV care providers in conversations with their reproductive-age patients about fertility desires and intentions: a historical review of the HIV epidemic in the United States. Am J Public Health. 2013;103(8):1357-66.

28. Finocchario-Kessler S, Dariotis JK, Sweat MD, Trent ME, Keller JM, Hafeez Q, Anderson JR. Do HIV-infected women want to discuss reproductive plans with providers, and are those conversations occurring? AIDS Patient Care STDs. 2010;24(5):317-23.

29. Mindry D, Wagner G, Lake J, Smith A, Linnemayr S, Quinn M, Hoffman R. Fertility desires among HIV-infected men and women in Los Angeles County: client needs and provider perspectives. Maternal Child Health J. 2013;17(4):593-600.

30. Squires KE, Hodder SL, Feinberg J, Bridge DA, Abrams S, Storfer SP, Aberg JA. Health needs of HIV-infected women in the United States: insights from the women living positive survey. AIDS Patient Care STDs. 2011;25(5):279-85.

31. World Health Organization. PMTCT strategic vision 2010-2012. Geneva: World Health Organization; 2010.

32. Kodzi IA, Johnson DR, Casterline JB. Examining the predictive value of fertility preferences among Ghanaian women. Demogr Res. 2010;26(22):965

33. Sufa A, Abera M, Admasu B. Utilization of family planning methods and associated factors among women living with HIV attending ART clinics in Nekemte Public Health Facilities, East Wollega Zone, Ethiopia. Sci Technol Arts Res J. 2014;2(4):71-7.

34. Demissie DB, Tebeje B, Tesfaye T. Fertility desire and associated factors among people living with HIV attending antiretroviral therapy clinic in Ethiopia. BMC Pregnancy Childbirth. 2014;14(1):382. 
35. Asfaw HM, Gashe FE. Fertility intentions among HIV-positive women aged 18-49 years in Addis Ababa Ethiopia: a cross sectional study. Reprod Health. 2014;20(11):36.

36. Worku D. Fertility intension and demand for family planning among people on ART follow up in North Wollo, Ethiopia. 2010. In: 21st annual public health conference.

37. Melaku YA, Zeleke EG, Kinsman J, Abraha AK. Fertility desire among HIVpositive women in Tigray region, Ethiopia: implications for the provision of reproductive health and prevention of mother-to-child HIV transmission services. BMC Women's Health. 2014;14:137.

38. Asfaw HM, Gashe FE. Fertility intentions among HIV-positive women aged 18-49 years in Addis Ababa Ethiopia: a cross sectional study. Reprod Health. 2014;11:36.

39. Alemayehu B, Aregay A. Desire to procreate among people living with HIV/AIDS: determinants in Ethiopia: a cross-sectional study. J AIDS HIV Res. 2012;4(5):128-35.

40. Getachew M, Alemseged F, Abera M, Deribew A. Factors affecting fertility decisions of married men and women living with HIV in South Wollo Zone, Northeast Ethiopia. Ethiop J Health Dev. 2010;24(3):214-20.

41. Warren EC, Abuya T, Askew I. Family planning practices and pregnancy intentions among HIV-positive and HIV-negative postpartum women in Swaziland: a cross sectional survey. BMC Pregnancy Childbirth. 2013;13:150.

42. Beyeza-Kashesya J, Ekstrom MA, Kaharuza F, Mirembe F, Neema S, Kulane A. My partner wants a child: a cross-sectional study of the determinants of the desire for children among mutually disclosed sero-discordant couples receiving care in Uganda. BMC Public Health. 2010;10:247.
43. Loufy MR, Hart TA, Mohammed SS, Su D, Ralph ED, Loufy MR, Hart TA, Mohammed SS, Su D, Ralph ED, Walmsley SL, Soje LC, Muchenje M, Rachlis AR, Smaill FM, Angel JB, Raboud JM, Silverman MS, Tharao WE, Gough K, Yudin MH. Ontario HIV fertility research team: fertility desires and intentions of HIV-positive women of reproductive age in Ontario, Canada: a cross-sectional study. PLoS ONE. 2009;4(12):e7925.

44. Regassa T, Fantahun M. Fertility desire and reproductive health care needs of men and women living with HIV/AIDS in Nekemte, East Wollege, Ethiopia. Sci Technol Arts Res J. 2012;1(3):31-8. www.starjournal.org. ISSN: 2226-7522.

45. Tamene W, Fantahun M. Fertility desire and family-planning demand among HIV-positive women and men undergoing antiretroviral treatment in Addis Ababa, Ethiopia. Afr J Aids Res. 2007;6(3):223-7.

46. Ethiopia Demographic and Health Survey, 2011.

47. Getachew M, Alemseged F, Abera M, Deribew A. Factors affecting fertility decisions of married men and women living with HIV in South Wollo Zone, Northeast Ethiopia. Ethiop J Health Dev. 2010;24(3):214-20.

48. Maier M, Andia I, Emenyonu N, Guzman D, Kaida A, Pepper L, Hogg $R$, Bangsberg DR. Antiretroviral therapy is associated with increased fertility desire, but not pregnancy or live birth, among HIV positive women in an early HIV treatment program in rural Uganda. AIDS Behav. 2009;13(1):28-37.

49. Saleem S, Bobak M. Women's autonomy, education and contraception use in Pakistan. A national study. Reprod Health. 2005. https://doi. org/10.1186/1742-4755-2-8.
Ready to submit your research? Choose BMC and benefit from:

- fast, convenient online submission

- thorough peer review by experienced researchers in your field

- rapid publication on acceptance

- support for research data, including large and complex data types

- gold Open Access which fosters wider collaboration and increased citations

- maximum visibility for your research: over 100M website views per year

At BMC, research is always in progress.

Learn more biomedcentral.com/submissions 